ÉGYPTE

monde arabe

\section{Égypte/Monde arabe}

$34 \mid 1998$

Droits d'Égypte : histoire et sociologie

\title{
Review Essay : Three Recent Views on the Implementation of Islamic Law
}

\section{Maurits S. Berger}

\section{(2) OpenEdition}

\section{Journals}

Édition électronique

URL : https://journals.openedition.org/ema/1542

DOI : 10.4000/ema.1542

ISSN : 2090-7273

\section{Éditeur}

CEDEJ - Centre d'études et de documentation économiques juridiques et sociales

\section{Édition imprimée}

Date de publication : 31 décembre 1998

Pagination : $272-279$

ISSN : 1110-5097

\section{Référence électronique}

Maurits S. Berger, «Review Essay : Three Recent Views on the Implementation of Islamic Law », Égypte/Monde arabe [En ligne], 34 | 1998, mis en ligne le 08 juillet 2008, consulté le 07 juillet 2022 URL : http://journals.openedition.org/ema/1542 ; DOI : https://doi.org/10.4000/ema.1542

Ce document a été généré automatiquement le 7 juillet 2022.

Tous droits réservés 


\title{
Review Essay : Three Recent Views on the Implementation of Islamic
} Law

\author{
Maurits S. Berger
}

\section{RÉFÉRENCE}

Sa'îd al-'Ashmâwî, al-Sharî'a al-islâmiyya wa-l-qânûn al-misrî, Cairo : Maktabat Madbûlî alSaghîr, 1996

Târiq al-Bishrî, Fîl-l-mas'ala al-islâmiyya al-mu'âsira. Al-wad' al-qânûnî al-mu'âsir bayn alsharî'a al-islâmiyya wa-l-qânûn al-wad'î, Cairo : Dâr al-shurûq, 1996

Muhammad al-Jâbrî, al-Dîn wa-l-dawla wa tatbîq al-sharî'a, Beirut : Markaz dirasât al-wad' al-'arabî, 1996

1 In the past two decades the movement of "political Islam» - also labeled « resurgence », « revival », or « renewal » of Islam - has dominated the agenda of most Muslim countries. The call for the implementation of sharîa law is one of the tenets of this movement This tenet, however, suffered from two shortcomings. First, the call for the sharî' $a$ turned out to be more a battle cry than a clear program. ${ }^{1}$ Many Muslims will agree that the sharî'a should be applicable to their daily life, but few will be able to indicate what this means or how this should actually be executed. Second, the discussion has been polarized: it was a "yes» (full implementation of sharîa law) versus a «no » (no implementation of sharî’a law). Moreover, the protagonists of sharî'a law advocated a revival of sharî'a law, the restoration of the sharîa to its old glory. In this clash between supporters and opponents of sharî'a law, the moderates who tried to take an inbetween position were either unheard or ostracized. It seems, however, that these moderates are slowly but surely emerging. They are Muslims who support the implementation of the sharì $a$, but who are in favor of an evolutionary rather than a revolutionary process. In addition, they have specific conceptions on what should be meant by sharî'a and to what extent and by which methodologies it should be 
implemented. Between the two extremes of the "yes" and the "no", these people have taken the middle position of the "yes, but » : Yes, shari” a should be implemented, but on certain conditions. ${ }^{2}$

In this review essay, aselection is made among these moderates based on three books published in 1996. The authors are the Egyptian former Court of Appeal and High Court of Security judge Sa'îd al-'Ashmâwî, the Egyptian State Council member Târiq al-Bishrî, and the Moroccan philosopher Muhammad al-Jâbrî. These books are interesting for various reasons. First, their authors do not blindly take a « yes» or « no » position, but break new ground for further developments of the shari' $a$. Second, it appears that they endeavor to reach a larger audience by abandoning the complex intellectual discourse so common among Arab intellectuals and choosing to write small books in a simple and distinct Islamic prose.

\section{Sharî'a and ljtihâd}

Before entering into the discussion of these books, some terminology which plays a key role in the arguments of their authors needs to be addressed.

According to orthodox Islamic dogma, the shari'a is the code of conduct of the Muslim. Its written sources are the Koran (which is the word of God) and the Sunna (the collection of hadith, which are the actions and sayings of the prophet Muhammad). From a legal point of view, this corpus of the sharî'a contains very few rules. Less than one percent of the Koran, for instance, can be considered legal rules, mostly dealing with family and inheritance law.

In the first four centuries of Islam, many legal scholars developed new legal rules and principles, based ideally on the two principle sources, the Koran and the Sunna. The scholarship of deriving these additional rules and principles is called the figh, which was also the term used for the extensive corpus in which they were collected.

The individual scholar who, through certain methodologies, derives rules from the two principle sources, is said to practice ijtihâd. According to orthodox Islamic dogma, this practice was stopped after four centuries (i.e. in the 4th century AH/10th century AD). It was said that « the gates of ijtihâd are closed ». One of the reasons for the prohibition of further ijtihâd was that four centuries of legal activity had provided enough rules, and no new rules were needed.

7 The main feature of the closing of the gates of ijtihâd is the cessation of direct access to the two principle sources, and complete reliance on the corpus of figh. Within the figh, however, new rules were allowed to develop, but technically speaking, however, this was not proper ijtihâd. From this period onward, one had to refer to the figh to know sharî'a rules. It is therefore not surprising that the terms figh and sharî'a are often interchanged. Two developments in the history of shari'a ate of importance for this review essay : the reopening of the gates of ijtihâd and the reintroduction of the sharî'a. Although modern scholars have reason to believe that the gates of ijtihâd were never really closed, 3the possibility of reopening these gates has been a much debated issue among Muslim scholars since the 19th century. Orthodox Islamic dogma, however, has so far not acknowledged the renewed activity of ijtihâd'with regard to the Koran and the Sunna. In Egypt, this has been recently confirmed by the Supreme Constitutional 
Court in March 1994 and in August 1996 by the Court of Cassation in the infamous Nasr Abu Zayd case. ${ }^{5}$

In the 20th century, the debate on reopening the gates of ijtihâd became overshadowed by the debate on reintroducing sharî'a law. In most new Muslim nation-states, much of sharî'a law was replaced by western laws and legal systems, and reintroducing sharî'a law became a political issue.

\section{Three Views}

9 The following paragraphs will present the three authors' arguments, beginning with a brief overview of the history of shari'a law. It will become apparent that the three authors view their past in completely different ways which, in turn, have a definite influence on how they see the future. Finally, a discussion of the main issue ensues: How to implement sharîa law?

\section{The Developments of Sharĩa Law in the Past}

Both Bishrî and 'Ashmâwî argue that sharîa law has been in decline in the past few centuries ('Ashmâwî, 1996 : 8-9; Bishrî, 1996 : 7). Their views on how this deterioration was halted, however, lead to diametrically opposed positions. According to 'Ashmâwî, it was western legal concepts that put the sharîa back on track again and saved it from further decline ('Ashmâwî, 1996 : 8-9).

Bishrî, on the other hand, argues that western concepts - and western influence in general - are the root of its decline. He argues that the much needed restoration of sharîa was already undertaken by Muslim scholars themselves, by the so-called " renewal » (tajdîd) movement of the 18th and 19th centuries (Bishrî, 1996: 8-12, 110 ff.). These scholars were debating the reopening of the gates of ijtihâd. These activities were radically interrupted by what Bishrî calls the European "aggression " (ghazwa). Instead of concentrating on restructuring Muslim society and its legal system, the renewal movement became submerged in an identity struggle and resistance against westernization. The basis of Bishrî's argument is that the initial activity of the renewal movement should be picked up again and continued.

Jâbrî sees the developments of sharîa law from another perspective. According to him, the present situation of social turmoil and the call for implementation of sharî $a$ law is just the natural course of Islamic history. Early Islamic society was a coherent social order, he explains, without external influences. The only unrest this young society had to deal with was its search for a unified doctrine of its new religion. The fundamentalist groups and movements that were causing havoc at that time were in disagreement on the doctrine of Islam ('aqîda), and not the application of the sharîa. Issues were the essence of God, His attributes, divine justice, free will, the nature of creation, and so forth (Jâbrî, 1996 : 152-153). Today, Jâbrî claims, the opposite is the case. The religion of Islamic societies is unified in orthodox Islam, but its social order is disrupted by foreign influences. Islamic societies are forced to reevaluate and determine their own social order. This is a matter of sharîa. Today's fundamentalist groups and movements do not disagree on religious matters, but on the application of the sharîa. Issues include the implementation ofIslamic laws, the veil, interest on money, criminal law (Jâbrî, 1996 : 151-155). From these historical developments, Jâbrî deduces an optimistic vision of the 
present situation : just as religious groups and antagonists in the past found "modem " methods and notions to "reconstruct" religious dogma and theology, so will the fundamentalist movements vanish when the science of the sharî' $\mathrm{is}$ " reconstructed " with modern methods and notions (Jâbrî, 1996 : 156).

\section{How Much Further? What Is Needed Is Renewal, Not Revival}

With regard to the present situation, the three authors are unanimous on a few points. They claim that the call for implementation of sharîa law has nothing to do with religion, but is motivated by social, economic, and political factors ('Ashmâwî, 1996: 20 ; Bishrî, 1996 : 49,104 ; Jâbrî, 1996 : 129, 133). They also argue that present Islamic society faces many problems, especially the lack of justice. They further agree that the solution to these problems is the implementation of sharîa law ('Ashmâwî, 1996: 10), provided it is not being revived and restored in its former position, but applied in a renewed form (Bishrî, 1996 : 49 ; Jâbrî, 1996 : 133). Here, the road between 'Ashmâwî on the one hand, and Bishrî and Jâbrî on the other, starts to diverge.

\section{'Ashmâwî : the Sharî'a Is Already Applied}

As mentioned above, 'Ashmâwî claims that the implementation of western legal systems and concepts has saved sharîa law from further deterioration. He argues that this implementation does not mean that sharîa law has been substituted by western laws. On the contrary, in Egypt, sharîa law is actually already implemented, infused with western concepts and laws which are not contradictory to sharîa law. « Egyptian law is ninety percent sharîa law » ('Ashmâwî, 1996 : 11).

15 'Ashmâwî reasons as follows. Since the sources of sharîa law (the Koran and Sunna) contain so few legal rules, implementation of sharìa law actually means implementation of figh ('Ashmâwî, 1996 : 25-26). Only the iigh provides the corpus and the framework for a legal system that can be implemented. Within the figh, it is permitted by orthodox Islam to adapt rules to place and time. It is therefore perfectly admissible and within the scholarly tradition of the fiqh, 'Ashmâwî continues his argument, to use western concepts and rules ('Ashmâwî, 1996 : 22).

He argues also that western influences in present Egyptian law are not foreign to Egyptian society or sharîa law. Most of Egyptian law is based on French law, which is based on Roman law. Sharîa law and Roman law, 'Ashmâwî argues, share the same legal and cultural heritage, and there are quite a few influences of Roman law in sharîa law ('Ashmâwî, 1996 : 31-35).

17 Finally, 'Ashmâwî states, the observation that sharîa law is actually already implemented in Egypt is not new. It was the conclusion reached in 1987 by the committee appointed by the Egyptian government to review Egyptian law according to its Islamic value. According to 'Ashmâwî, the committee's conclusion was again confirmed in 1995 by the famous TV-preacher Sha'râwî and the shaykh al-Azhar, Gâd alHaqq ('Ashmâwî, 1996 : 11-12).

\section{Jâbrî and Bishrî : Reopen the Gates of ljtihâd}

18 Jâbrî and Bishrî continue where 'Ashmâwî leaves off : sharî'a law still needs to be implemented, albeit in a renewed form. Their concern is not so much with the actual 
rules of shari'a law, but its methodology. Both advocate the use of the legal theoretical framework of the sharîa, and both argue that it is necessary to regain direct access to the primal sources of the sharîa in order to formulate new solutions. In other words, the gates of ijtihâd should be reopened. But these gates are not merely to be opened; the ijtihâd advocated by Jâbrî and Bishrî needs to be a « renewed » ijtihâd.

Bishrî emphasizes that sharîa rules should not be followed blindly, but serve as an inspiration, a divine blueprint for further legislation (Bishrî, 1996 : 124). There is no unique way to implement sharîa law, he says. There are different ways, depending on the Islamic society where it is implemented, just as there are different implementations of « democratic » and " socialisf systems in European countries (Bishrî, $1996: 78$ ).

According to Jâbrî, the «old » ijtihâd is no longer usable : « The [old] ijtihâd which has been shaped by life is of no use to the present, and the past has no use for it anymore " (Jâbrî, 1996: 166). The main problem of the "old " ijtihâd is that it tends too much towards a literal interpretation of the rules of the Koran and Sunna. The changes in «Muslim culture » demand a « renewal of its roots », i.e. renewal « in-depth, but also from depth» (fi al-a'mâq wa min al-a'mâq) (Jâbrî, 1996: 134). He advocates a « reconstruction » of the science of the sharîa by means of a modern ijtihâd.

21 Jâbrî justifies this adaptation of the " old " ijtihâd within the context of the sharîa. The method of legal reasoning as prescribed by the «old» ijtihâd might have become sacrosanct, he argues, but its principles are not prescribed by the Koran or Sunna. They are man-made, developed by the legal scholars in the first centuries of Islam. This means that «nothing prevents us from developing other legal methodologies, as long as they realize the wisdom of the Legislation in a particular period in the best possible way » (Jâbrî, 1996 : 179).

\section{The Immutability of Sharîa Rules}

The relation between sharî'a and figh rules is the most delicate subject in the debate on the implementation of sharî'a law. Bishrî and 'Ashmâwî are very explicit in separating the shari' $a$ from the figh. The sharîa has as sources the Koran and the Sunna. These rules are untouchable. The figh, on the other hand, is man-made law and adapted to circumstances of time and place ('Ashmâwî, 1996 : 25 ; Bishrî, 1996 : 25-26,35-36,99-100).

Bishrî takes this distinction literally. The rules of the Koran and Sunna are an untouchable blueprint for eternity and for every place. They are "non-historic and superseding time and place», and they are "the source of legal and institutional legality » (masdaral-shar'iyya al-qânûniyya wa-l-nidhâmiyya) (Bishrî, 1996: 91). The few rules it contains, such as divorce, inheritance portions, hudûd, etc., are therefore immutable (Bishrî, 1996 : 107). Legislative freedom only exists within the context of the figlr. " figh is a positive, historical [corpus] : we take from it and we leave it according to what we perceive in the sources of Islam [i.e. Koran and Sunna] as modem, taking into account that the figh is a historical expertise which needs to be studied; it is the experiences (tajârib) of the past from which we seek guidance. » (Bishrî, 1996: 37) It is within this context that Bishrî sees the necessity of practicing a renewed form of ijtihâd (Bishrî, 1996 : 102).

According to Bishrî, implementation of sharîa does not.mean the implementation of certain rules, but « the return to the source of Islamic legality, to be sovereign, and the standard measure of ruling, and the legislative source for human actions and 
institutions as well as for values for behavior in accordance with ethics (akhlâq) (...). This does not mean seeking laws and orders to replace those promulgated by the state, nor [does it mean] the call to set its laws aside. (...) The aim is a situation in between " (Bishrî, 1996 : 124).

25 'Ashmâwî takes a more liberal view with regard to the sharîa $a$. As demonstrated above, 'Ashmâwî argues that the call for the application of sharîa is actually the call for the application of the figh - ninety percent of which is implemented in Egypt. The sharî $a$ might come back into the picture with the remaining ten percent. In that case, 'Ashmâwî argues, sharîa rules should not be applied literally. The sharîa is not only rules and principles but it is first (...) a general atmosphere which rules the community. " ('Ashmâwî, 1996: 73) Sharîa law should only be applied "within the framework that is wished by the Great Legislator » ('Ashmâwî, 1996: 91). With regard to the hudûd, the criminal offences described in the Koran, for instance, he argues that they are limited by the figh, and are only applicable in a community of believers. Society, therefore, should first be changed in accordance with the spirit of islam before the hudûd are implemented ('Ashmâwî, 1996 : 72).

Jâbrî takes an even more liberal view and advocates a complete renewed approach : "What is needed today is a renewal, not based on the continuation of ijtihâd in the furû » [i.e. figh] but on resourcing the sources (i'âdat ta'sîlal-usûl) [i.e. the sharî'a] and on reconstructing them" (Jâbrî, 1996: 157). Like 'Ashmâwî, Jâbrî argues that when practicing ijtihâd, one should focus on the meaning of the rules of the Koran and sharî $a$ rather than on the literal text. The legal reasoning should be inspired by the sharì $a$ in order to " realize God's wisdom. » But Jâbrî continues his argument by. stating that the general purpose of the sharî - or God's wisdom - is the common interest of a society (maslaha) (Jâbrî, 1996 : 52-53, 164-165, 169-172). This legal concept was developed by the Muslim scholar al-Shâtibî in the 8th century $\mathrm{AH}^{6}$ and is vehemently rejected by Bishrî (Bishrî, 1996 : 130).

In addition, Jâbrî advocates that sharîa rules be seen in a historical and social context. He gives the example of the hadd punishment of cutting off the thief $s$ hand. This punishment was justifiable in a Bedouin nomadic society which lived in harsh conditions, without jails, police or central power. Today, Jâbrî argues, the social context has changed, and although a thief still needs to be punished, modern means and institutions have made the hadd punishment obsolete (Jâbrî, 1996 :175).

\section{Conclusion}

The call for implementation of the sharîa is as old as Islam itself, and is not a whim of the 1970s and 1980s. The implementation of shari'a does not exist. This review essay shows that there are many possible views between the extreme position of full unconditional implementation of the sharî $a$ and complete rejection of it.

The views of the three Muslim Arab authors discussed in this essay are interesting for a number of reasons. They are the vanguard of Muslim «moderates » that dare to speak out in the vicious battle between opponents and proponents of implementation of sharîa law. Their maxim is: Yes, the sharîa should be applied, but on certain conditions. All three agree that implementation should take place not by revolution, but by an evolutionary process through legislation. Their main concern is that Islamic society benefits from this implementation. Implementation, therefore, should take 
place in a new adopted form. The authors also agree that the necessary changes in society cannot come about by legislation alone, but need to come from within society. The conditions by which sharîa law should be implemented is also an issue of contention between the authors. 'Ashmâwî argues that sharîa law is in effect already implemented in Egypt, since Egyptian law in most cases does not contradict sharîa law. Jâbrî and Bishrî argue that sharîa law still needs to be implemented, and both advocate the reopening of the doors of ijtihâd. But where Jâbrî advocatesa liberal interpretation of sharîa rules based on the common interest of the community,Bishrî takes the conservative view that sharî'a rules are not to be altered.

\section{NOTES}

1. See Ayubi, Nazih (1991), Political Islam: Religion and Politics in the Arab World, London: Routledge ; Roy, Olivier (1994), The Failure of Political Islam, London : I. B. Tauris (original French version : 1992).

2. See for an overview and classification of these thinkers Ayubi (1991: 201-213). In this article I deliberately use the vague term "moderate " to avoid discussion of rather unclear definitions such as «neo-lslamist, liberal Muslim », or « reformist ».

3. See for instance Hallaq, Wael (1984), «Was the gate of ijtihâd really closed?», International Journal of Middle Eastern Studies 16 : 3-41.

4. Dupret, Baudoin (1997), « À propos de la constitutionalité de la sharî'a », Islamic Law and Society 4(1) : 91-113.

5. See Berger, Maurits and Dupret, Baudoin (1998), «Extraits de la jurisprudence Abû zayd », in this issue.

6. See for instance, Masud, M. K (1995), Shatibi's philosophy of Islamic law, Islamabad : International Islamic University.

INDEX

Mots-clés : loi islamique, sharî’a

\section{AUTEUR}

MAURITS S. BERGER

University of Amsterdam 